This item was submitted to Loughborough's Research Repository by the author.

Items in Figshare are protected by copyright, with all rights reserved, unless otherwise indicated.

\title{
Utopianism and prefiguration
}

PLEASE CITE THE PUBLISHED VERSION

https://cup.columbia.edu/book/political-uses-of-utopia/9780231179591

PUBLISHER

(C) Columbia University Press

VERSION

AM (Accepted Manuscript)

LICENCE

CC BY-NC-ND 4.0

REPOSITORY RECORD

Kinna, Ruth. 2019. “Utopianism and Prefiguration”. figshare. https://hdl.handle.net/2134/19278. 


\section{Utopianism and Prefiguration}

\section{Ruth Kinna}

For anarchists, utopias are about action. As Uri Gordon argues, utopias are "umbilically connected to the idea of social revolution". ${ }^{1}$ The kind of action utopia describes is a matter of debate. This essay examines how utopian thinking shapes anarchist thought and highlights some recent shifts in the political uses of utopia. Utopianism is not treated as an abstract concept or method, nor as a literary genre or place - because that is not how anarchists have understood the idea. Utopia, Gordon notes, "has always meant something more than a hypothetical exercise in designing a perfect society". As a revolutionary idea, utopia is instead linked to the principle of prefiguration.

Prefiguration has been identified as a core concept in contemporary anarchist thinking and it is increasingly invoked to highlight the distinctiveness of anarchist practices, actions and movements. In 2011, two months after the start of Occupy Wall Street, David Graeber identified prefigurative politics as one of the movement's four characteristically anarchist principles, the other three being direct action, illegalism and the rejection of hierarchy. Hinting at the utopianism of the concept, he described Occupy as a genuine attempt "to create the institutions of the new society in the shell of the old". Pursuing the idea, he linked prefiguration to the creation of "democratic General Assemblies", consensus decision-making and a range of mutual aid, self-help institutions - including "kitchens, libraries, clinics, media centres". ${ }^{2}$ The

\footnotetext{
${ }^{1}$ Uri Gordon, "Utopia in Contemporary Anarchism" in L. Davis and R. Kinna (eds), Anarchism and Utopianism, (Manchester: Manchester University Press), 2009, p. 260.

${ }^{2}$ David Graeber, “Occupy Wall Street's anarchist roots”, Aljazeera Opinion 30 November 2011 http://www.aljazeera.com/indepth/opinion/2011/11/2011112872835904508.html. Last access 31 Januaruy 2014.
} 
spontaneous emergence of these bodies and practices attested to the practicality of radical aspirations, in ways that might be deemed to be at odds with the traditional idea of utopia as an imaginary realm of ideal non-existence or impossibility. Yet insofar as actions like Occupy expose the flimsiness of official dismissals of egalitarian social change, captured in the mantra TINA, they are also utopian.

While there is little dispute about the centrality of prefiguration in anarchist literatures, there is considerable variation about the utopian politics that prefigurative action variously encourages and rules against. The essay shows how blueprint utopianism (associated with the mid-nineteenth century utopian socialists) serves as a foil for contemporary anarchism. It also touches on Abensour's well-known framing of 'utopia as desire' in order to illustrate the dovetailing of anti-utopian utopianism with some recent conceptions of anarchist utopianism. By examining debates about the interrelationship of these two concepts and, in particular, the continuities and discontinuities in the history of anarchist thought, it is possible to capture the spectrum of utopian political practice which prefiguration describes, extending from a utopian commitment to a sociological framing of alternatives to a dystopian embrace of a psychology of desiring.

\section{Prefiguration}

For Benjamin Franks prefiguration is the principle anarchists use to assess the legitimacy of actions and he defines concept in terms of a relationship between ends and means. A core anarchist commitment, he argues, is that "means have to prefigure ends". ${ }^{3}$ In normative political theory, the commitment to prefiguration leads anarchists to reject both consequentialism, the idea

\footnotetext{
${ }^{3}$ Benjamin Franks, Rebel Alliances: The Means and Ends of Contemporary British Anarchisms, (Edinburgh \& Oakland: AK Press and Dark Star, 2006), p. 13.
} 
that the outcomes of actions are the proper measures of rightness, and deontology which instead considers the justness of actions in terms of duty, or conformity with established norms or laws. ${ }^{4}$ Prefiguration, Franks argues, steers anarchists towards virtue ethics, a position that grounds morality in character or behaviour and the intentions of actors. In addition, Franks associates prefiguration with what he terms "pragmatic ethics". This means that anarchists reject instrumentalism, or the principle that "the success of a plan is determined by its efficiency in meeting the objectives". Franks associates instrumentalism with Max Weber. However, his elision of instrumentalism with consequentialism leads him to identify a range of exponents, from J.S. Mill to Lenin, and even to apply it to doctrines which seek to decouple the evaluation of action from considerations of rightness by the substitution of mere "necessity". Machiavellianism and Nechaevism are examples. In contrast to this broad body of thought, anarchist prefiguration collapses the distinction between means and ends. In terms reminiscent of Gandhi's anarchist-friendly precept to be the change you wish to see, Franks argues that actions "embody the forms of social relation that actors wish to see develop". ${ }^{6}$ The political implications are that everyday behaviours are central to anarchist practice and that the choices individuals make in the conduct of their lives provide a primary locus for anarchist actions. This understanding is echoed by Cindy Milstein. Prefiguration, she argues, is

the idea that there should be an ethically consistent relationship between the means and the ends. Means and ends aren't the same, but anarchists utilize means that point in the direction of their ends. They choose action or projects based on how these fit into longer-terms aims.

\footnotetext{
${ }^{4}$ Franks, pp. 17-18.

${ }^{5}$ Franks, p. 101.

${ }^{6}$ Franks, p. 114.
} 
Anarchists participate in the present in the ways that they would like to participate, much more fully and with much more self-determination, in the future - and encourage others to do so as well. Prefigurative politics thus aligns one's values to one's practices ... ${ }^{7}$

The priority attached to intention as a standard of rightness is not new in anarchist thought. The nineteenth-century anarchist Peter Kropotkin defended the assassins of Alexander II in 1881 in precisely these terms. ${ }^{8}$ Similarly, anarchism has long been associated with the rejection of instrumentalism: Weber framed his critique of Tolstoy in terms of the priority anarchists attached to the "ethics of ultimate ends" over the "ethics of responsibility". 9 Yet the term "prefiguration" does not appear in nineteenth century anarchist discourses, at least not commonly. For some contemporary writers this absence is significant and its emergence in the last two decades or so captures sense that there has been a shift in thinking, or perhaps in emphasis, in contemporary anarchist thought in the post-second war period. ${ }^{10}$ Indeed, some tie the concept tightly to recent activism. The strong association sometimes made between labour organizing and historical anarchism, on the one hand, and the dichotomy between social and lifestyle anarchism, on the other, has encouraged this view (though proponents of prefiguration overwhelmingly reject the

\footnotetext{
${ }^{7}$ Cindy Milstein, Anarchism and Its Aspirations, (Edinburgh \& Oakland/Washington: AK Press/IAS, 2010), p. 68.

${ }^{8}$ Peter Kropotkin, “Anarchist Morality”, in Roger Baldwin (ed), Kropotkin's Revolutionary Pamphlets (New York: Dover Books, 1970), p. 100.

${ }^{9}$ On Tolstoy and Weber see Sam Whimster (ed.) Max Weber and the Culture of Anarchy (Basingstoke: Palgrave Macmillan, 1999).

${ }^{10}$ Prefiguration is a familiar term in English-language anarchism but it does not feature in Daniel Colson's Petit Lexique philosophique de l'anarchisme de Proudhon à Deleuze, (Paris: Librairie Générale Française, 2001).
} 
critique of lifestyle that Murray Bookchin advanced when he cemented this distinction). ${ }^{11}$ To give one example, in "Trying to Occupy Harvard” Philip Cartelli notes:

Since the beginning of Occupy Wall Street, much has been made of its prefigurative politics - an increasingly popular mode of political organization and practice among grassroots movements of the Left over the past half-century that models the kind of democratic society in which they aspire to live. In my experience, however, such radical lifestyle politics are more likely to appeal to activists outside of traditional political groupings such as labor unions or specific issue and policy-oriented organizations. ${ }^{12}$

Marianne Maeckelbergh offers a similar account, tracking prefiguration through post-war feminism, "the anti-nuclear and peace movements, the racial justice movements in the US, anticolonial and anti-developmentalism movements in the global South, and later the do-it-yourself and environmental movements-all of which fed into the alterglobalization movement that challenged the right of multilateral organizations (WTO/WB/IMF/G8) to rule the world". ${ }^{13}$ In this context prefiguration is an expression of counter-cultural politics which disappeared at the end of the ' 60 s to re-emerge in recent anti-capitalist campaigns. And rather than attach to "anarchism" as such - a doctrine suggestive of thick ideological commitment and defined

\footnotetext{
${ }^{11}$ Murray Bookchin, Social Anarchism of Lifestyle Anarchism: An Unbridgeable Chasm, (Oakland, CA and Edinburgh: AK Press, 1995).

${ }^{12}$ Philip Cartelli, "Trying to Occupy Harvard", in the series Occupy, Anthropology, and the 2011 Global Uprisings, Jeffrey Juris and Maple Razsa (eds.), Cultural Anthropology, 2012 http://culanth.org/fieldsights/63-occupyanthropology-and-the-2011-global-uprisings. Last access 31 January 2014.

${ }^{13}$ Marianne Maeckelbergh “Horizontal Decision-Making across Time and Place”, Jeffrey Juris and Maple Razsa (eds.), Cultural Anthropology, 2012 http://culanth.org/fieldsights/63-occupy-anthropology-and-the-2011-globaluprisings. Last access 31 January 2014.
} 
practice - prefiguration is instead linked to practices, free from specific content. Maeckelbergh finds the contrast in old-style programmatic politics.

The practices today find their predecessors in movements of the 1960s, when activists questioned on a large scale the need for a unitary political program of revolutionary change (in other words, the need to determine ahead of time the one thing your movement is 'for'). These ideas often took the form of practicing 'participatory democracy' and building 'autonomous' social relations. ${ }^{14}$

The narrowly workerist assumptions about the character and composition of the historical movement are contestable. Moreover, the identification of prefigurative politics with particular waves of activity or forms of practice betrays a tendency to historicism which is difficult to reconcile with the types of agency that prefiguration spotlights. The significance of the meansends dynamic in prefigurative politics is not that it maps actions to a prescribed set of approved forms, but that it rules against judgments based on the consideration of outcomes or, at least, results determined by anyone other than the "local agent". ${ }^{15}$ Similarly, the weight attached to the choices that activists make when engaging in action is not that prefiguration results in moral consensus or political uniformity, but only that it supports direct action: the power of transformation is placed in the hands of individuals, acting by themselves and/or in collaboration with others.

\footnotetext{
${ }^{14}$ Maeckelbergh "Horizontal Decision-Making across Time and Place"

${ }^{15}$ Franks, p. 114.
} 
In current discourse, prefiguration is used to describe the creative power of collective struggles, ${ }^{16}$ the project of building of a new world in the heart of the old, either in the ordinary sense of the word, as a foreshadowing, ${ }^{17}$ or to describe ways in which revolutionary desires are expressed in respect of the intimate relationship between social transformation and action in the present. ${ }^{18}$ Like Franks, David Graeber places the commitment to direct action in everyday life at the heart of prefigurative discourses. ${ }^{19}$ Prefiguration is linked to creativity, subversion, playfulness and to the development of alternative relationships and ways of living. Prefigurative politics, Federico Campagna and Emanuele Campiglio argue, "go hand in hand with the desire for long-term, broad-horizon imagination"; prefiguration is about "the continuous exercise of testing the imaginary landscapes against the necessities and the subterranean flows of daily life". ${ }^{20}$

In all these senses, prefiguration contests the frequent and unthinking association of anarchism with destruction, and instead stresses the experimental, productive and innovative characteristics of anarchist practices that challenge and seek to replace or challenge hierarchical and oppressive social forms. As Franks argues, prefigurative politics describes the rejection of

\footnotetext{
${ }^{16}$ Christian Marazzi, "Exodus Without Promised Land”, Preface Frederico Campagna and Emanuele Campiglio (eds) to What We Are Fighting For A Radical Collective Manifesto, (London: Pluto Press, 2012), p. viii-ix.

17 The Anarchist FAQ talks about "the future in the present", see the discussion of blueprints at: http://anarchism.pageabode.com/afaq/secI2.html. Last access 31 January 2014.

${ }^{18}$ Uri Gordon defines prefigurative politics as a practice: the "actual implementation and display of anarchist social relations", Anarchism and Political Theory: Contemporary Problems, PhD thesis, University of Oxford, 2007, ch. 3, accessible at http://theanarchistlibrary.org/library/Uri_Gordon_Anarchism_and_Political_Theory_Contemporary_Problems.ht ml Last access 31 Juanuary 2014.

${ }^{19}$ David Graeber, "The New Anarchists", New Left Review, n 13, Jan-Feb 2002, 62; Campagna and Campiglio, "Introduction: What Are We Struggling For?" in What We Are Fighting For, p. 5.

${ }^{20}$ Campagna and Campiglio, "Introduction: What Are We Struggling For?” p. 5.
} 
vanguardism and the "scientific" certainties on which revolutionary elitism has been constructed and the repudiation of the varieties of socialism that vanguard strategies have produced classless but nevertheless highly centralized and industrialized dictatorships. ${ }^{21}$ Just as it refuses the imposition of even fleeting, temporary dictatorial means, prefiguration embraces actions that achieve nothing more than transitory, momentary gains in autonomy. The local, direct actions that bring these gains about foster behaviors that are transformative. In sum, prefiguration rules out certain approaches to social change, but leaves the specification of behaviours open to activists. In this respect, and in the context of debates about the continuities and discontinuities of the historical and modern anarchist movements, Franks's approach to prefiguration appears malleable both to the politics of the nineteenth-century, to post-second war campaigns and contemporary forms of activism. Nevertheless, as the relationship between utopianism and prefiguration reveals, the utopianism of the historical movement appears to rule against this application. In Franks's terms, the suspicion is that these forms of utopianism admit a gap between means and ends, compromising prefiguration by directing action towards the realization of predetermined goals.

\section{Prefiguration and Utopianism}

It is common to find contemporary anarchists describe prefiguration as a utopian politics. In Anarchism and Its Aspirations Cindy Milstein argues that envisioning a world "beyond hierarchy" is "part of prefiguration". And hinting at the continuity of anarchist thought, she suggests that by adopting prefigurative politics, contemporary anarchism "retains a utopian

\footnotetext{
${ }^{21}$ See for example Carl Boggs, "Marxism, prefigurative communism, and the problem of workers' control", at: http://libcom.org/library/marxism-prefigurative-communism-problem-workers-control-carl-boggs.
} 
impulse". ${ }^{22}$ Milstein's defence of anarchist utopianism is advanced explicitly as a rejection of two other types. Utopia, she argues, is neither "a thought experiment. Nor is it a blueprint or rigid plan”. Franks makes a similar point. Prefiguration, he argues, is compatible with utopianism but he qualifies the ways in which it is so; and he shares Milstein's worry is that utopias typically fall into one of two main types: abstract ideal or blueprint. The first runs counter to prefiguration by stripping action of practical content and the second by enforcing an ideal social arrangement that renders prefigurative engagement impossible. Returning to the dynamic of the means-ends relationship, Franks argues that the role of utopian thinking cannot be to delineate the "end" or purpose of action, for this encourages both consequentialism and statist thinking: both the idea that the prospect of end mitigates the harms of the means deployed for its achievement and, in the first place, that the goal can be pre-determined.

The conception of utopianism that Franks and Milstein are most concerned to resist is the one painted by anti-utopian liberals, which links utopianism to rigid social planning, moral perfectionism and the totalitarian determination of individual well-being. In these schemas, utopians often appear as dangerous fantasists, completely out of touch with reality and blind to the social costs of their ideals. In critical literatures on anarchism, this kind of utopianism is typically inscribed in portraits of Bakunin. ${ }^{23}$ Milstein's response is to treat utopia as a method linked to practice rather than a descriptor of a social condition. Anarchist utopianism "dreams up ways to embody its ethics, and then tries to implement them". ${ }^{24}$ Parecon, Michael Albert's model of participatory economics, might be considered an example of this approach, though it is

\footnotetext{
${ }^{22}$ Milstein, Anarchism and Its Aspirations, p. 66.

${ }^{23}$ For a recent discussion of liberal anti-utopianism see Lucy Sargisson, Fool's Gold: Utopianism in the Twenty-first Century (Basingstoke: Palgrave/Macmillan, 2012, pp. 22-31.

${ }^{24}$ Milstein, Anarchism and Its Aspirations, p. 67.
} 
not an example she cites. ${ }^{25}$ Franks follows a similar tack. In prefigurative politics, he contends, utopia might illustrate anarchist principles, model their practical operation, inspire actions or provide a springboard for the development of new critical discourses, as long as it does not serve as the end itself.

In addition, Franks adds a psychology of action. Anarchist utopianism, he argues, might be regarded as a myth, comparable to Sorel's myth of violence. Like the Sorelian myth, anarchist utopianism is unaffected by the failure of its achievement: ${ }^{26}$ to borrow Milstein's neat formulation, "[a]narchists are used to loss". ${ }^{27}$ In this guise, the myth indicates an eternal willingness to endure the impossibility of success as a condition of struggle. In addition, anarchist utopianism shares the Sorelian myth's irrational qualities, which Franks captures in the notion of desire. In the light of anti-utopian liberal critique, the invocation of Sorel appears odd; as Mark Antliff argues, both the Janus-faced nature of Sorel's thought and the appeal to anesthetized violence is deeply problematic. Nevertheless, Antliff's careful analysis of Sorel also helps explain why myth remains attractive to contemporary activists as "a catalyst for revolutionary inspiration". For Sorel, Antliff notes, “myths presented the public with a visionary ideal whose stark contrast with present reality would agitate the masses". His invocation of the myth was a marker of the role he attached to emotion and intuition in social action. It was also a sign of his rejection of "rational planning" and, more pointedly, the idea, which he associated with socialist reformism, of using social blueprints to delineate policies of incremental action. ${ }^{28}$

\footnotetext{
${ }^{25}$ For a recent, pithy description of Parecon see Michael Albert "Participatory Economics From Capitalism", in Campagne and Campiglio (eds) What We Are Fighting For, pp. 11-17.

${ }^{26}$ Franks, Rebel Alliances, p. 105.

${ }^{27}$ Milstein, Anarchism and Its Aspirations, p. 65.

${ }^{28}$ Mark Antliff, "Bad Anarchism: Aestheticized Mythmaking and the Legacy of Georges Sorel”, Anarchist Developments in Cultural Studies, Art and Anarchy, 2011, pp. 162-3.
} 
A strong a tradition of critical anarchist thinking, stretching back to Proudhon's refusal of all systems, attests to the anti-utopianism Franks and Milstein describe. Anarchism's antiutopianism was cogently re-stated by Rudolf Rocker. ${ }^{29}$ Nevertheless, the association of anarchism with abstraction and blueprint utopianism infuses a lot of contemporary anarchist thinking. The title of Christian Marazzi's preface to What We Are Fighting For, "Exodus Without Promised Land" hints at persuasiveness of anarchist self-criticism. ${ }^{30}$ More pointedly, Uri Gordon, Simon Tormey and Saul Newman have advanced the critique and sought to distance contemporary anarchism from dominant nineteenth-century doctrines. Kropotkin is often identified as an exponent of the wrong sort utopianism: a form that is inflexible, focused on the destination rather than the journey and rooted in abstract, essentialist conceptions of nature and human flourishing. In Newman's recent work, the relevant distinction is between

'scientific utopianism', in which a future anarchist society is founded on scientific and rational principles and will be the inevitable outcome of a revolution against the state; and another that might be termed 'utopianism of the here and now', in which the focus is less on

\footnotetext{
${ }^{29}$ Rocker argued: "Anarchism is no patent solution for all human problems, no Utopia of a perfect social order (as it has so often been called), since, on principle, it rejects all absolute schemes and concepts. It does not believe in any absolute truth, or in any definite final goals for human development, but in an unlimited perfectibility of social patterns and human living conditions which are always straining after higher forms of expression, and to which, for this reason, one cannot assign any definite terminus nor set any fixed goal." Rudolf Rocker, Anarchism and Anarcho-Syndicalism, online at https://libcom.org/library/anarcho-syndicalism-rudolf-rocker-chapter-1. Last access 31 January 2014.

${ }^{30}$ Gordon, "Rethinking Revolutionary Practice", p. 166; Simon Tormey, "From Utopian Worlds to Utopian Spaces" Ephemera, 5 (2005), pp. 394-408. http://www.ephemerajournal.org/issue/organisation-and-politics-social-forums. Last access 31 January 2014.
} 
what happens after the revolution, and more on a transformation of social relations within the present. $^{31}$

Franks' discussion of twentieth-century utopian political theory helps uncover the reason why historical anarchist traditions have been persistently identified with blueprint utopianism. His view, that anarchists are more open to engagement with postmodernism than other types of socialist, (specifically Leninists), because of the fluid conceptions of utopia that postmodernism supports, points to theoretical developments in the field of utopian studies. Miguel Abensour's scholarship has been extremely influential here. In a recent discussion, which Newman recommends, Abensour defines utopianism as an idea of "becoming", a term he uses to describe an ontological condition linked to the creativity, individuality and inventiveness of desire. There is a broad sense in which utopianism captures a particular desire, but it is not one that can be given content. Persistent utopias, in distinction to "eternal forms", designate "a stubborn impulse toward freedom and justice - the end of domination, of relations of servitude, and of relations of exploitation". This impulse is an "orientation toward what is different, the wish for the advent of a radical alterity here and now". 32

These innovative developments in utopian studies tend to historicise forms of utopian antiutopianism, largely in critique of vulgar Marxist traditions, much in the same way that contemporary activists historicise prefigurative politics. Yet the divergence of anarchist and Marxist historical traditions is rarely noted and the result is that the convergence of anarchist utopianism and contemporary utopian anti-utopianism is not treated, as Franks argues, as a shift in utopian thinking, but as a revision of anarchism. Thus for Newman, the dovetailing informs

\footnotetext{
${ }^{31}$ Saul Newman, The Politics of Postanarchism, (Edinburgh: Edinburgh University Press), 2011, p. 162.

${ }^{32}$ Miguel Abensour, "Persistent Utopia". Constellations, 15 (2008), pp. 406-421.
} 
the rejection of two currents: one which associates nineteenth-century socialist traditions with workerism and a second that treats socialism as an enlightenment philosophy which automatically places utopian visions in a box marked abstraction or blueprint. However, another reading of history is possible and the openness of contemporary "here and now" anarchist utopianism to forms of postmodern thinking which Newman and others link to parallel modifications in historical anarchism can equally be explained by the critical distance between anarchist utopian thought and other forms of socialist utopianism. As David Leopold has argued, the conventional "utopian" and "anti-utopian" dressing of nineteenth-century socialism conceals significant differences in the structure of revolutionary political thought. ${ }^{33}$

In the nineteenth century, arguments about utopianism were often rehearsed in the context of an extended debate about the role of the state's repressive tools as instruments of revolutionary transformation. Divisions on this issue became markers of ideological commitment. Anarchists and other anti-authoritarians firmly rejected the idea that the state's powers might be used in this way and argued that the contrary position assumed a model of change that was elitist and therefore self-defeating. Babeuf and Blanqui were identified as the progenitors of this strategy. The strategies that anarchists proposed in response were utopian, but not in the sense in which authoritarians usually painted utopian traditions - typically by referring to fantastical and pointless blueprints. The important indicator of utopianism as an alternative to the elitism of authoritarian socialism was the expression of anarchist ideals through direct actions that plotted means consistently to the ends of struggle. For example, in Bakuninist insurrectionary models of change, the destruction of individual ownership rights - recorded in land registers - was often identified as a means of revolutionary change and it mapped to a

\footnotetext{
${ }^{33}$ David Leopold, “The Structure of Marx and Engels' Considered Account of Utopian Socialism”, History of Political Thought, 26 (3), (2005), pp. 443-466.
} 
particular end: the abolition of private property. The destruction of the registers was a symbolic act through which the landless rid themselves of the formal legal protections that supported property rights and the system of rural exploitation and oppression that they sanctioned. The idea of the general strike followed a similar logic, but instead of burning records of property ownership, workers instead took immediate, direct control of the land and factories and abandon production for profit. The Tolstoyan model was rather different, involving multiple individual acts of refusal, in addition to collective actions, notably to participate in systems of conscription and regimes of punishment. Here, action was directed towards the realization of peaceful coexistence and non-violence is the required means. For Kropotkin revolution had an insurrectionary aspect but it was underpinned by a principle of collective withdrawal. The ends were captured in the principle of mutual aid. The appropriate means was the construction of political, social and economic networks, organized beyond the reach of the state, which would both ensure that activists had access to basic necessities in periods of violent repression and intense combat, and that the social relations capable of sustaining anarchist practices were brought into being, prior to the state's collapse. ${ }^{34}$

Just as anarchists accused authoritarians of focusing on issues of efficiency or necessity in developing revolutionary strategy - the same critique that Franks' attaches to Leninism - they were also wary of abstraction. In Bakunin's work the means-end relationship was underpinned by an understanding of conceptual contestability. Socialists, he argued, were united in their commitments to "equality, freedom, justice, human dignity, morality and the well-being of individuals". But these were not ends as such, since the meaning of these abstract ideas was always open to interpretation: they took on a particular hue when they were "mapped by a few

\footnotetext{
${ }^{34}$ Peter Kropotkin, “Anarchism: Its Philosophy and Ideal” in Baldwin (ed.) Kropotkin’s Revolutionary Pamphlets, p. 140.
} 
sages or savants". ${ }^{35}$ The utopian element of his anarchism was filled out by a vision of ordinary people negotiating conceptual meanings through struggle and the process of self-organization, having once thrown off the shackles of their enslavement in a direct act of insurrection. Kropotkin and Gustav Landauer developed their utopian alternatives through the critique of socialist theories of history, which they considered abstract. ${ }^{36}$ Their special concern was to highlight the structure of Marx and Engels' scientific socialism and show that anarchist utopianism stood some distance from it. Marx, they argued, denied he was a utopian yet he conjured a vision of the future by rooting socialism in a theory of change that assimilated prevailing norms, practices and institutional forms, and ridiculed other, imaginative visions as impractical or whimsical dreams. The hallmarks of their utopianism were first, the possibility of working practically towards the realization of a different politics and second, the space that existed for creative thought and moral judgment in shaping that politics. In this, Kropotkin aligned himself with early-century utopian socialists - particularly with Charles Fourier - both to show the continuity of anarchism with these traditions and in order to probe the possibilities of realizing a better (more beautiful, emotionally rich, humane, convivial) future than the one that history, without intervention, seemed most likely to otherwise deliver. ${ }^{37}$ However, in appealing

\footnotetext{
${ }^{35}$ Michael Bakunin, "Stateless Socialism: Anarchism”, from G.P. Maximoff (ed) The Political Philosophy of Bakunin, online at http://dwardmac.pitzer.edu/Anarchist_Archives/bakunin/stateless.html

${ }^{36}$ Ruth Kinna, "Anarchism and the Politics of Utopia" in Davis and Kinna (eds) Anarchism and Utopianism, (Manchester: Manchester University Press, 2009), pp. 221-240.

${ }^{37}$ For a discussion of Marx's utopianism see Leopold "The structure of Marx and Engels' considered account of utopian socialism", and David Leopold, "Socialism and (the rejection of) Utopia”, Journal of Political Ideologies, 12 (3), pp. 219-237.
} 
to conceptions of desire, he explicitly rejected the phalanstery and the classification of personality types that Fourier's science defined. ${ }^{38}$

As Franks suggests, contemporary anarchists recognize an affinity with forms of utopianism that reject scientism, a pervasive feature of dominant forms of historical socialism. Yet the consistent feature of anarchist thinking about utopianism is the prefigurative framing of social transformation - a framing that in different ways was designed to challenge principles of certainty and inevitability. Utopia was not held up as "the end" in the means-ends relationship, but invoked in order to assert the possibility of different alternatives, each dependent on direct action and the principle of desire. As utopians, anarchists elaborated strategies for change consistent with their anti-authoritarian principles precisely in order to resist unspecified abstract utopias and blueprints.

Acknowledging the open-textured character of historical anarchist utopianism and its consistency with contemporary prefigurative politics suggests a possible recasting of Franks's conception of prefiguration. Franks defines prefiguration in dyadic terms and argues that anarchism collapses the distinction between means and ends. His recognition of the utopian element in prefigurative politics indicates that prefiguration describes a triadic relationship and that anarchist utopianism mediates the means and ends of anarchist action, injecting it with a set of possibilities that make sense of their ethical inter-relationship. In a discussion of the Committee of 100, Nicholas Walter made the point in this way: "unilateral nuclear disarmament as the end, and mass non-violent action as the means". The utopian ideas that brought the end and means into a prefigurative relation was the vision of Britain that embraced revolutionary solutions to existing social problems, had banned the bomb, left NATO, disengaged from the

\footnotetext{
${ }^{38}$ For a discussion of Kropotkin and Fourier see Matthew Adams, "Rejecting the American Model: Peter Kropotkin’s Radical Communalism”, History of Political Thought, 35 (2014), pp. 147-173.
} 
Cold War and adopted "positive neutralism", rejecting "colonialism abroad and racialism at home" ${ }^{39}$ Utopianism might have different flavours, but in order to be prefigurative, anarchist recipes for the cookbooks of the future must include this ingredient.

Questioning the conjunction of historical anarchism with rigid utopianism also challenges the contention that the shifts that Franks observes within utopian studies map neatly to an evolution within anarchism from abstract or blueprint utopianism, on the one hand, to "here and now" utopianism on the other. By resetting the relationship between anarchism and utopian studies it is possible to locate the significant shifts in the anarchist politics of utopia elsewhere. Even though there are considerable overlaps between historical and contemporary forms of prefigurative politics, the detectable change lies in the psychology of action that Franks refers to in his discussion of Sorel. In other words, the distancing of contemporary from historical anarchism has encouraged a move away from positively utopian aspiration and towards the dystopian framing of utopian desire.

\section{Anarchism and the Political Uses of Utopia}

Removing anarchist utopianism from the binominal taxonomies that distinguish historical, workerist, ideological anarchism from contemporary anti-ideological horizontalism reveals the existence of a spectrum of utopian, prefigurative practices and suggests a number of distinct political uses for utopia in contemporary activism. Utopias might be fleshed out sociologically at one end of this spectrum and appear as nebulous possibilities, vehicles for the principle of desire, at the other. The danger of invoking a harsher historicized transformation of anarchist utopianism, crystallized in the concept of prefiguration, is that a particular set of approaches to

\footnotetext{
${ }^{39}$ Nicholas Walter, "The Committee of 100: Ends and Means" in David Goodway (ed) Damned Fools in Utopia And Other Writings on Anarchism and War Resistance, Oakland, CA: PM Press, p. 79.
} 
social change are valued at the cost of others. Recognizing the spectrum on which anarchist utopianism rests admits a diversity of prefigurative practices.

Contemporary literature shows that utopianism supports diversity in activism. Among the prefigurative practices that contain strongly sociological currents are a number of grass-roots community projects. Shaun Chamberlain, for example, describes the "force for a better future" in a project of community building, fostering a collective psychology of hopefulness. In a discussion of the Transition movement he argues, "if despair is perceiving an undesirable future as inevitable, one glimpse of a realistic, welcome alternative transforms our despondency into a massive drive to work towards that alternative. ${ }^{, 40}$ In a similar spirit, Mark Smith advocates a form of practical utopianism that models ecological ways of living through the estimation of global risk. ${ }^{41}$ There is at least a hint of Proudhon and Kropotkin in these approaches and a resounding echo in Franco "Bifo" Berardi's conception of utopian possibility:

As Force and Reason have failed as principles of social change and political government, I think that we should adopt the point of view of the tendency, not the point of view of the will. Tendency is not an ideal, a utopia, it is not the projection of a rational order that force would eventually implement. Tendency is a possibility implicated in the present state of things, a possibility that cannot currently be deployed because the present paradigm of social relations ... makes such deployment impossible. ${ }^{42}$

\footnotetext{
${ }^{40}$ Shaun Chamberlain "The Struggle for Meaning” in Campagna and Campiglio (eds.) What We Are Fighting For, p. 45 .

${ }^{41}$ Mark J. Smith "Practical Utopianism and Ecological Citizenship", in Campagna and Campiglio (eds) What We Are Fighting For, p. 82.

${ }^{42}$ Franco "Bifo" Berardi "The Transversal Function of Disentanglement" in Campagne and Campiglio, What We Are Fighting For, p. 144. Kropotkin argued in very similar terms. In "Anarchist Communism" he wrote: "As to the method followed by the anarchist thinker, it entirely differs from that followed by the utopists. The anarchist thinker
} 
Utopias that prioritise psychologies of action often revolve around the creation of autonomous space and the transformation of every-day social relationships. Dreams and visions still have a place in these strands of prefigurative practice. Ben Lear and Ralph Schlembach's recent discussion of hope and despair includes a central demand, "luxury for all", which is reminiscent of William Morris's call for wealth and the abandonment of riches. Utopia provides a way of moving beyond the despair that capitalism induces by providing a "basis of our hope, not in capitalist development, but in its confrontation and eventual abolishment". Their antiutopian utopianism bears some other hallmarks of his utopian romance.

Our hope is ... non-utopian in the sense that we are not in the business of painting detailed pictures of what a post-capitalist society will look like. That does not mean that we cannot imagine or experiment with social relationships that are not dominated by the logic of accumulation and valorisation ... What we do say when we talk about an alternative is that we reject the logic of capital. The vision of a post-capitalist world is not one of paradise; ...we can, and must imagine a future where the production of wealth is no longer tied to class divisions and the labour relation. ${ }^{43}$

does not resort to metaphysical conceptions ... to establish what are, in his opinion, the best conditions for realizing the greatest happiness of humanity ... He studies society and tries to discover its tendencies ... He distinguishes between the real wants and tendencies of human aggregations and the accidents (want of knowledge, migrations, ward, conquests) which have prevented these tendencies from being satisfied”. In Baldwin (ed.) Kropotkin's Revolutionary Pamphlets, p. 47.

${ }^{43}$ Ben Lear and Ralph Schlembach, “If You Don't Let Us Dream, We Won't Let You Sleep?” in Alessio Lunghi and Seth Wheeler (eds.), Occupy Everything: Reflections on why it's kicking off everywhere, (Brooklyn: Minor Compositions, n.d.), 43-44. 
Nevertheless, a striking trend in prefigurative politics is towards dystopian escape, rather than utopian achievement. Lear and Schlembach's conclusion is that indignation can powerfully be brought bear on change and that the "unwillingness to imagine bigger political alternatives" contributes to the "sense of despair and rage" that activists feel. In other activist writing, the idea is taken a step further. Utopia captures a boundless politics, but one described negatively as desire to resist, reject or destroy. Mark Fisher evokes an idea of perpetual motion, rooted in a psychological drive against death: statis. "As desiring creatures" Fisher notes "we ourselves are that which disrupts organic equilibrium", or the tendency towards regulation, direction and control. $^{44}$

Paul Goodman's discussion of utopianism offers a useful way of thinking about this recasting of prefigurative politics. In a discussion of grief and anger Goodman linked utopianism to patience. Patience, he argued, did not mean calm. On the contrary, utopianism was also a trigger for violent passions: anger, about the obstacles to the realization of utopian desire and grief, for things understood to be absent through the identification of that desire. Utopians were patient in the sense that they were prepared to wait for the emergence of felt desire, through their anger and grief. This meant that utopian desire always had an object and it involved effort in the present in order to secure its attainment - Goodman's anticipation of prefiguration. In contemporary activism, the positive value attached to the ability to tap negative passions despair, indignation, hatred and particularly rage - does not suggest that utopian patience has been eclipsed. But their invocation suggests a narrowing of contemporary anarchist utopianism and in the notion of prefigurative practices open to activists. John Holloway's discussion of anti-

\footnotetext{
${ }^{44}$ Mark Fisher "Post-capitalist Desire" in Campagne and Campiglio What We Are Fighting For, p. 135.
} 
capitalist rage captures the mood. His concern is to channel the forces of destruction rather than confront their negativity:

Break the windows of the banks, shoot the politicians, kill the rich, hang the bankers from the lampposts. Certainly, all that is very understandable, but it does not help very much. It is money we must kill, not its servants. And the only way to kill money is to create different social cohesions, different ways of coming together, different ways of doing things. Kill money, kill labour. Here, now. ${ }^{45}$

This most negative casting of means-end relationship remains prefigurative and is perhaps reminiscent of Bakunin's famous declaration that the passion for destruction is a creative passion, too. The difference is that the righteous expression of rage, indignation or despair often appears in contemporary literature as a condition of being rather than of doing. Moreover, it depends on the conjuring of powerfully dystopian images of existing society, which variously ensnares, entraps and enslaves individuals. In the light of this dystopian imagery, the generalized emotions which radicals seek to release increasingly resemble those that Paul Goodman cautioned against when he contrasted desire "without its object" and the adoption of "the role of being angry", to the desire for something and the ability to blaze against the obstacles to its achievement. The ends of change are not only described with deliberate vagueness, even when linked to practical activities, but the analysis of means is developed as pulling away, less a pushing toward. Goodman explained the enraging desire to desire as a sense of lost paradise or the idea of "paradise not yet", but rather than endorsing this idea as an impulse to eternal

\footnotetext{
${ }^{45}$ John Holloway, Afterword, in Campagne and Campiglio What We Are Fighting For, p. 204.
} 
struggle, as Abensour suggests, he rejected it as a cause of continuous frustration. ${ }^{46}$ The negatively and dystopianism of contemporary prefiguration changes the focus for action, tends against the specification of hopes and desires and undercuts the positive charge that Bakunin excludes in his destructiveness. The power of this imagery might well help facilitate common actions, masses, occupations and demonstrations, and the new types of social cohesion that Holloway advocates, even whilst the ends and means of protest are defined in a variety of different ways. Yet it is difficult to accommodate the horizontal practices and behaviours expressed through mutual aid in protest organizations and community campaigns in these dystopian frameworks, for they seem to exist "outside" the real world in a manner that makes their operation appear partial or compromised or impossible. Linked to a more positively utopian politics, this kind of activity might support a variety of ends and means and might even remain indeterminate, but in any of its forms, it would be possible for everyone - participant and observer, friend and enemy alike - to appreciate the complex ways in which actions might be designed to prefigure utopian goals. Looking again at anarchist history helps uncover some political uses of utopia that might contribute to such an approach.

\footnotetext{
${ }^{46}$ Paul Goodman, “On the Intellectual Inhibition of Grief and Anger”, Utopian Essays and Practical Proposals, (New York: Vintage Books, 1962), p. 93-109.
} 